pag

Business School

WORKING PAPER SERIES

Working Paper

2014-365
The Evolution of Risk Premium as a Measure for Intra-regional Equity Market Integration

Khaled Guesmi

Frederic Teulon

Ahmed Taneem Muzaffar

http://www.ipag.fr/fr/accueil/la-recherche/publications-WP.html

IPAG Business School

184, Boulevard Saint-Germain

75006 Paris

France 


\title{
The Evolution of Risk Premium as a Measure for Intra-regional Equity Market Integration
}

\author{
Khaled Guesmi \\ Department of Finance, IPAG Research Lab, IPAG Business School, France \\ \& EconomiX, University of Paris Ouest La Défense \\ Email: khaled.guesmi@ipag.fr \\ Frederic Teulon \\ Department of Finance, IPAG Research Lab, IPAG Business School, France \\ Email:f.teulon@ipag.fr
}

\author{
Ahmed Taneem Muzaffar \\ School of Business, University of Western Sydney, Australia \\ Email:taneemm@yahoo.com
}

\begin{abstract}
We estimate and test the conditional version of an international capital asset pricing model using a parsimonious multivariate GARCH process and the multivariate nonlinear least squares method. Since our approaches are fully parametric, we can recover any quantity that is a function of the first two conditional moments. Our findings strongly support using a model that includes both regional market and foreign exchange risk. However, both sources of risk are detected only when their prices are allowed to change over time. Our empirical results show clear evidence of market integration to varying degrees, explained by the U.S term premium and the level of market openness. Though it reaches high values during turmoil periods and exhibits an upward trend towards the end of the estimation period, the Indonesian stock market remains partially integrated into the ASEAN-5 regional market. These results suggest that diversification into Indonesian market assets continues to produce substantial profits and that asset pricing rules should reflect a state of partial integration.
\end{abstract}

Keywords: time-varying integration, risk premium, ICAPM, multivariate GARCH.

JEL classification: C32, F36, G11. 


\section{Introduction}

The Asian financial crisis has led regional governments to cooperate in several attempts at financial integration. For example, the 2000 Chiang Mai initiative involving the ASEAN + 3 was an attempt to create a range of swap arrangements that would allow member countries to protect themselves against speculative attacks when their fundamental positions were sustainable. Most of the swap arrangements enable a country under attack to obtain US dollars from the other countries as long as it is taking adequate countermeasures, such as an IMFendorsed program. Though regional financial integration has not been driven by the solid sense of political purpose that has characterized its European counterpart, Asian countries have observed that European integration has been a source of regional strength and stability and have wondered what might be developed for their own benefit. Most of the interest in the financial field has focused on monetary integration, not simply because that is technically much easier to achieve than is financial integration but also because the Asian crises were primarily foreign exchange crises, which spilled over into banking crises, particularly in Indonesia. The focus of action has been on developing bond markets, particularly through the Chiang Mai initiative, which enables a network of currency swaps to be activated among the member countries. The consensus is that the Asian crisis occurred largely because countries had difficulty matching both currencies and maturities in the turbulent period; deeper bond markets might have been able to recover much more rapidly. The fact that a large share of corporate and bank liabilities were denominated in a foreign currency has been recognized as a major factor in the vulnerability of the financial systems of most Asian economies (Borensztein and Loungani, 2011). This crisis has shown that contagion effects can be important even when regional financial integration is limited. The fear of a new financial contagion has pushed countries to engage in a concerted effort to develop instruments for promoting greater financial stability in the face of external shocks. Our objective is to determine whether Indonesia could be a locus of financial stability in Asia.

The literature on this subject (Bekaert and Harvey, 1995; Carrieri et al., 2007) shows that the expected returns of listed shares on emerging stock exchanges depend not only on the national economy's characteristics but also on the degree of the emerging markets' integration in global finance. Efficient allocation strategies in emerging countries like Indonesia require a careful analysis of their risk-return trade-off as well as their linkages with the global stock market. Interactions with the developed world make the Indonesian market's returns vulnerable to changes in other markets and may thus wipe out portfolio diversification 
benefits.

Although previous studies (Adler and Qi, 2003; Guesmi, 2011; Carrieri and al. 2007; Guesmi and Nguyen, 2011) have provided a general understanding of the global integration of emerging markets in recent decades (Errunza and Losq, 1985; Bekaert and Harvey, 1995; Carrieri et al., 2007; Pukthuanthong and Roll, 2009), little attention has been paid to the intraregional integration of emerging markets into regional markets, an undeniable trend. Moreover, the possibility that the structural reforms undertaken by emerging countries lead to time-varying shifts in the integration process governing stock-market return dynamics has rarely been considered, producing a biased assessment of the degree of financial integration.

This study contributes to the literature by developing a dynamic international capital asset pricing model (ICAPM) that allows for smooth transitions between integration regimes: expected returns may move from a perfectly-segmented regime to a perfectly-integrated one, or vice versa, depending on the U.S term premium and the level of market openness. Although the proposed model was developed in the spirit of that offered in Bekaert and Harvey (1995), it allows for the dynamic conditional correlations between stock returns by using the multivariate GDC-GARCH model of Engle (2002). It also enables us to examine the relevance of the dynamic measure of financial integration over the conditional correlations, frequently used in the literature to describe integration levels. Our study differs from past studies in that we investigate the integration of emerging market regions into the ASEAN-5 region, rather than into the global market, using the real effective exchange (REER) as a common source of risk, in addition to regional and local sources.

Our findings clearly show that the degree of Indonesia's market integration varies over time, and that the U.S term premium and level of market openness serve as the chief explanations of that degree. Despite reaching high values during turmoil periods and exhibiting an upward trend towards the end of the estimation period, the Indonesian market remains partially integrated into the regional one.

Our analysis is relevant for both policymakers and investors interested in stock markets and their integration. Our examination of the links between stock markets is of particular interest to financial players; portfolio managers monitor stock market fluctuations to infer the trend of each market and make diversification decisions. Moreover, the degree of market integration is a crucial issue for the world economy during turmoil periods. Measuring the impact of financial crises on integration degrees also provides useful information about 
possible substitution strategies between stock classes. Specifically, integration levels are key to hedging possibilities, while they also impact asset allocation and their risk-return tradeoffs.

The rest of this paper is organized as follows. Section 2 presents a brief review of the literature on financial integration in emerging markets. Section 3 describes our empirical approach to measuring and investigating levels of stock market integration over time. Section 4 presents the data. Section 5 discusses the study's results, and Section 6 provides some concluding remarks.

\section{Literature on the integration of emerging markets}

Discussing emerging stock markets requires that financial integration levels be considered. Relevant studies may be grouped into two main categories: those that test the perfect integration hypothesis of international capital markets, and those that test the hypothesis of partial integration. We will discuss only a few major papers among the extensive body of literature.

Harvey (1995) tests the international version of the capital markets (CAPM) model on 20 emerging markets. He concludes that the MSCI world index is not pertinent, given the low betas obtained, indicating that emerging markets are not fully integrated into the world market. This result remains unchanged after being adjusted for the effect of discontinuous trading.

The rejection of the perfect integration hypothesis naturally supports the idea that emerging markets are partially integrated, which can be tested using the methodology in Stehle (1977). The author proposed using a conditional ICAPM, in which the expected return on an asset depends on both the global systematic risk represented by the covariance between the asset and the world market portfolio and the local systematic risk represented by the covariance between the asset and the national market portfolio. In the absence of exchange rate risk, Stehle (1977) derives two alternative testable versions: a pricing model for an integrated state and a model for a segmented state. The first model requires that an asset's expected return be a function of the global systematic risk and the "adjusted" local systematic risk, corresponding to the uncorrelated portion between the national and world market portfolios. Under the null hypothesis of perfect integration, the local beta should be zero. The pricing model for segmented markets is constructed in a similar fashion, with the roles of the local and global systematic risks reversed. 
Bekaert and Harvey (1995) agree with the partial integration view but deny the validity of static measures of market integration. Accordingly, they develop an alternative model combining the two extreme cases of perfect segmentation and integration; at each point in time, expected return on an asset (or a market) depends simultaneously on a global risk factor weighted by an integration coefficient and a local risk factor weighted by a segmentation coefficient. This model is reduced to a domestic CAPM for strictly segmented markets and to an international CAPM for perfectly integrated markets. Bekaert and Harvey (1995) apply their nested model to 12 emerging markets and show that their integration level changes over time.

Adler and Qi (2003) examine Mexico's integration into the North American market from 1991 to 2002. The authors generalize the Bekaert and Harvey (1995) model to include the peso/dollar exchange-rate risk and show that integration levels dropped during crises and began to rise again in the early 2000s. Additionally, the exchange rate risk was priced and relevant in explaining variations in the stock returns of the Mexican equity market. Carrieri et al. (2007) extend the model in Errunza and Losq (1985) to assess the integration levels of 8 emerging markets using an aggregated measure of financial asset substitution. They argue that full integration is achieved if we can construct a diversified portfolio from all the eligible assets, whose returns mimic those of a portfolio composed of all the assets in an ineligible segment, and that, conversely, full segmentation corresponds to a null correlation between these two portfolios. These results show that the local pricing factor continues to be relevant in the valuation of emerging market assets but that none of the markets examined is completely segmented from the world market. The authors also question the use of marketwide index correlations as indicators of financial integration, which such indicators significantly underestimate.

Chambet and Gibson (2008) attempt to estimate the degree of integration among 25 emerging markets by using a dynamic model that incorporates not only local and global pricing factors but also a systematic risk factor for emerging markets. The conditional variances are allowed to fluctuate according to a multivariate $\mathrm{GARCH}(1,1)$-in-mean process. This paper is particularly interesting in that the authors attempt to explain their integration measure through several economic variables, including the degree of openness and market concentration. The results show that a number of emerging markets remain segmented and that segmentation levels are negatively correlated with degrees of market openness and the diversification of a country's trade structure. 
Berger and Posi (2013) suggest a measure of financial integration based on the conditional variances of the country-specific and common international risk premiums in equity excess returns. An inspection of the time profile of the proposed integration measure for Germany, France, the UK, the US, and Japan from 1970 to 2011 shows that all countries exhibit several shorter periods of disintegration. The authors conclude that stock market integration is a dynamic process whose levels fluctuate in the short run while gradually increasing in the long run.

Guesmi and Nguyen (2014) investigate the dynamics of regional financial integration and its determinants in the context of an ICAPM accounting for the temporal variations in both regional and local risk sources. Examining four major countries in southeastern Europe, they show that the degree of trade openness and local stock market development are the most important determinants of regional financial integration; degrees of market integration saw frequent changes over the study period, and their dynamic patterns differed greatly across the markets examined.

Our study first focuses on the dynamics of Indonesia's regional financial integration in an environment of multiple sources of systematic risks, structural change, and interactions between the return series. We then examine the portions of the returns explained by regional and local risk factors through a decomposition of the total risk premium. Our empirical results differ from previous studies in that we test the hypothesis of time-varying intra-regional integration instead of considering global integration. Our international asset-pricing model characterizes market integration dynamics through time, in consideration of the gradual removal of barriers to emerging market investments. We also examine the portions of the returns explained by regional and domestic risk factors, respectively, by carrying out a decomposition of the total risk premium.

\section{Empirical Methodology}

Our empirical asset pricing model takes as its point of departure that in Bekaert and Harvey (1995) and is inspired by the theoretical partial integration models in Black (1974), Stulz (1981), Cooper and Kaplanis (2000), Hardouvelis (2006), De Santis et al. (2003), Carrieri et al. (2007), and Guesmi and Nguyen (2014). These authors confirm the partial integration hypothesis and time-varying world market integration for most individual markets. Exchange rate risk is also found to be priced in the context of both developed and emerging markets.

We adopt a partially integrated conditional ICAPM with three sources of systematic risk 
that globally reflect regional stock market, national stock market, and exchange rate fluctuations. The conditional mean excess return can be written as

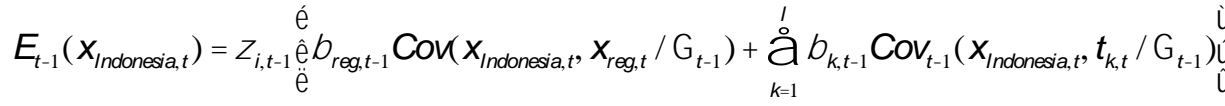

$$
\begin{aligned}
& +\left(\begin{array}{lll}
1 & t_{1}
\end{array}\right) \quad{ }_{i, t} \operatorname{Var}_{t 1}\left(X_{\text {Indonesia, } t} / t_{t 1}\right) \\
& \text { with } \\
& r_{r e g, t 1}=e^{\left(r_{r e g} G_{t 1}\right)} \\
& { }_{t 1}=e^{\left(D_{t 1}\right)} \\
& k, t={ }_{k} G_{t 1} \\
& { }_{t 1}=e^{\left|F_{t 1}\right|}
\end{aligned}
$$

where $X_{\text {Indonesia, }}, X_{\text {reg, } t}$ and $X_{k, t}$ represent (respectively) the expected excess returns on the local market portfolio, the excess return on the ASEAN-5 region (ASEAN and Australia, Korea, China, India, and Japan), and the excess currency return, conditional on a set of information $t_{t 1}$ available to investors up to time $t$-1. Moreover, $t_{k, t}^{c}$ is the return on the exchange rate of the currency of country $k$ against the dollar.

Cov is the conditional covariance between the security returns and the regional market returns.

reg,t 1 is the conditionally expected regional price of covariance risk.

$k, t 1$ expresses the expected price of the exchange risk for currency $k ; l$ is the number of markets included in the sample. Exponent $c$ indicates that returns are expressed in the currency of the reference country.

$i, t 1$ is the conditionally expected local price of variance risk.

$i, t, 1$ is the conditional probability of a transition between segmentation and integration states, which falls within the interval $[0,1]$ and can thus be interpreted as a conditional measure of the integration of market $i$ into the regional market. If $i_{t, 1}=1$, only the covariance risk is priced, and the strict segmentation hypothesis is rejected. If $i_{i, t}=0$, the unique source of systematic risk is the variance, and the pricing relationship in a strictly segmented market applies.

$G_{t-1}, D_{t-1}$, and $F_{t-1}$ denote (respectively) the vector of regional information variables, the vector of local information variables, and the vector of integration variables, all available at time $(t-1)$.

The stock market is fully integrated into the regional market when ${ }_{t 1}=1$; in this case, the 
expected return on the Indonesian market depends upon its covariance with regional stock market and exchange rate returns. Thus, the model in Eq. (1) becomes the two-factor regional CAPM allowing for deviations from purchasing power parity (PPP). If $t_{1}=0$, the Indonesian market is completely segmented from the regional market. The expected return is therefore determined uniquely with respect to the local market risk, and the model in Eq. (1) is reduced to the domestic CAPM. When $t_{t}$ is between 0 and 1 , the Indonesian market is partially integrated into the regional one, and the asset pricing relationship is based on a combination of regional, local, and exchange rate risk factors.

We employ the multivariate general dynamic covariance (GDC) proposed by Kroner and $\mathrm{Ng}$ (1998). They illustrate that the choice of a multivariate volatility model can lead to substantially different conclusions in an application involving forecasting dynamic variance matrices. More precisely, the econometric specification of the international asset-pricing model to be estimated (i.e., system of equations [1]) is characterized by the following system:

$$
\begin{aligned}
& x_{\text {Indonesia,t }}={ }_{t 1}\left[{ }_{\text {reg, } t 1} h_{\text {Indonesia, }}+{ }_{k, t} h_{\text {Indones }, k, t,}\right]+\left(\begin{array}{ll}
1 & { }_{t 1}
\end{array}\right)_{t 1} h_{\text {Indonesia, } t}+{ }_{\text {Indonesia, } t} \\
& x_{\text {reg, } t}={ }_{\text {reg, } t 1} h_{\text {reg }, t}+{ }_{k, t} h_{\text {reg, } k, t}+{ }_{\text {reg }, t} \\
& t_{k, t}={ }_{r e g, t 1} h_{r e g k, t}+{ }_{k, t 1} h_{k, t}+{ }_{k, t} \\
& { }_{t}=\left(\text { Indonesia, }, \text { reg, }, k_{k, t} /{ }_{t 1}\right) \sim \mathrm{N}\left(0, \mathrm{H}_{\mathrm{t}}\right) \\
& H_{t}=D_{t} R_{t} D_{t}^{\prime}+\otimes{ }_{t}
\end{aligned}
$$

where

$$
\left\{\begin{array}{l}
D_{t}=\left(d_{i j t}\right), d_{i j t}=\sqrt{i i t}, d_{i j t}=0 \\
t=\left({ }_{i j t}\right) \\
{ }_{i j t}=w_{i j}+a_{i}^{\prime} t_{1} '_{t 1}^{\prime} a_{j}+b_{i}^{\prime} H_{t 1} b_{j}+g_{i}^{\prime} t_{t 1}{ }_{t 1} g_{j} \\
a_{i}, b_{i}, g_{i} \quad i=1, \ldots 3 \\
={ }_{i j,}, i j=0 \quad i,{ }_{i j}={ }_{j i}
\end{array}\right.
$$

$H_{t}$ is the variance-covariance matrix of returns at time t. The dynamic correlation structure $R_{t}$ is specified by Tse and Tsui (2002) as follows:

$$
R_{t}=\left(1-\theta_{1}-\theta_{1}\right) R+\theta_{1} \Psi_{t-1}+\theta_{2} R_{t-1} \text { with } 0 \leq \theta_{1}+\theta_{2} \leq 1 .
$$

where $R=\left(\rho_{i j}\right)$ is a symmetric positive definite parameter matrix with $\rho_{i j}=1$, and $\Psi_{t-1}$ is the correlation matrix of $\varepsilon_{\tau}$ for $\tau=t-M, t-M+1, \ldots, t-1 . \tau=t-M, t-M+1, \ldots, t-1 .{ }^{1}$ Its $i j^{t h}$ element is given by

\footnotetext{
${ }^{1}$ For a complete review, see Duchesne and Lalancette (2003).
} 


$$
\begin{aligned}
& i, j, t 1=\frac{u_{i, t 1} u_{j, t 1},}{\sqrt{\sum_{m=1}^{M} u_{i, t \quad m}^{2} \div{ }_{m=1}^{M} u_{j, t}^{2} m} \div} \\
& u_{i, t}=\frac{i, t}{\sqrt{h_{i i, t}}}
\end{aligned}
$$

The matrix $\Psi_{t-1}$ can be expressed as $\Psi_{t-1}=B_{t-1}^{-1} L_{t-1} L_{t-1}^{\prime} B_{t-1}^{-1}$, where $B_{t-1}$ is a diagonal matrix with $i^{\text {th }}$ diagonal element.

The estimation of the vector of unknown parameters is carried out by the quasi-maximum likelihood estimation (QMLE) method as proposed by Bollerslev and Wooldridge (1992) to avoid the problem of non-normality in excess returns. Given the highly nonlinear structure of the model and the large unknown parameters number, a simultaneous estimation of the model is not feasible. We thus follow the literature (e.g., Hardouvelis et al., 2006; Guesmi and Nguyen, 2011) and estimate the system (2) in two steps to study the regional integration process. In the first stage, we estimate a subsystem of equations for excess returns on the regional and individual markets and the currency return plus the relevant variance-covariance elements with the multivariate GDC-GARCH process. This step produces the conditional variances of the Indonesian market, the real exchange rate, their conditional covariances, and the prices of the regional market and exchange rate risks. In the second stage, we use the multivariate nonlinear least squares to estimate the price of the local market risk and the timevarying level of integration.

\section{Data}

We consider a set of global, regional, and local instrumental variables that have been used by many relevant studies (summarized in Table 1). These factors are expected to provide information about the evolving prices of regional and local markets and degrees of market integration from March 31, 1996, to December 30, 2012. Data concerning these information variables are obtained from MSCI and the IMF's International Financial Statistics databases.

Table 1. Instrumental Variables

\begin{tabular}{lll}
\hline Variables & Measurement & Previous works \\
\hline$\underline{\text { Regional instrumental variables }}$ &
\end{tabular}




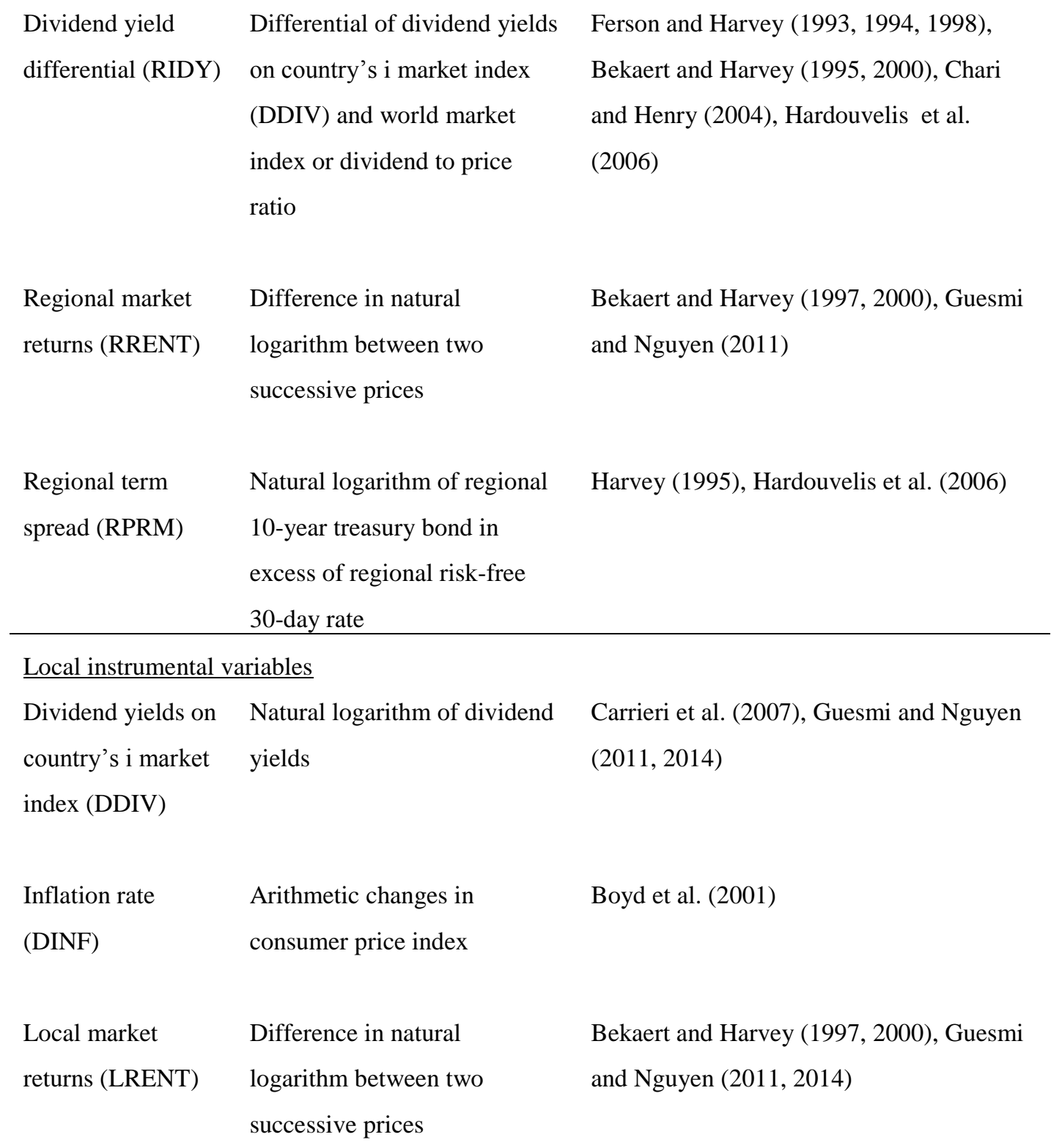

\section{$\underline{\text { Integration Factors } * * *}$}

\begin{tabular}{lll}
$\begin{array}{l}\text { US term spread } \\
\text { (UPRM) }\end{array}$ & $\begin{array}{l}\text { Natural logarithm of US 10- } \\
\text { year treasury bond in excess } \\
\text { of US risk-free 30-day rate }\end{array}$ & $\begin{array}{l}\text { Harvey(1995), Hardouvelis et al. (2006), } \\
\text { Guesmi and Nguyen (2011, 2014) }\end{array}$ \\
\hline $\begin{array}{lll}\text { Level of market } \\
\text { openness (MOPN) }\end{array}$ & $\begin{array}{l}\text { Total trade with the world to } \\
\text { GDP ratio }\end{array}$ & $\begin{array}{l}\text { Bekaert and Harvey (1997, 2000), Rajan } \\
\text { and Zingales (2001), Bhattacharya and }\end{array}$ \\
& & $\begin{array}{l}\text { Daouk (2002), Carrieri et al. (2007), } \\
\text { Carrieri et al. (2007), Guesmi and Nguyen } \\
\text { (2011, 2014) }\end{array}$ \\
\hline $\begin{array}{l}\text { Real exchange rate } \\
\text { index (REER) }\end{array}$ & $\begin{array}{l}\text { Logarithmic changes of real } \\
\text { exchange rates }\end{array}$ & $\begin{array}{l}\text { Hardouvelis et al. (2006), Guesmi and } \\
\text { Nguyen (2011, 2014) }\end{array}$ \\
\hline
\end{tabular}

Notes: ***The choice of only two variables allows us to avoid the numerical convergence problem when the number of explanatory variables for integration is above two. In practice, we have attempted to estimate our 
model using different numbers of market integration determinants, but the specification with two factors (i.e., trade openness and U.S. term premium) avoids the convergence problem and provides the best fit to the data, as witnessed by the AIC, BIC, and log-likelihood criteria (see Guesmi and Nguyen, 2014).

Table 2 presents the descriptive statistics for the stock market and real exchange rate returns. The skewness coefficients are positive, denoting that the returns distributions are skewed toward the right and that the probability of observing extreme negative returns is higher than that for a normal distribution. The kurtosis coefficients are significant and greater than three, revealing the leptokurtic behavior of returns distributions. Overall, the nonnormality of all the return series is clearly confirmed by the Jarque-Bera test.

The return distributions deviate significantly from normality, as seen in the Jarque-Bera test results. The Ljung-Box test of order 12 reveals that stock returns are subject to serial correlation.

Table 2: Descriptive Statistics of Return Series

\begin{tabular}{lcccccc}
\hline & Mean & Std. dev. & Skewness & Kurtosis & J.B & Q(12) \\
\hline Malaysia & -0.074 & 0.072 & 0.941 & 4.395 & 45.332 & $68.86+++$ \\
Singapore & -0.049 & 0.023 & -0.075 & 5.660 & 69.957 & $75.97+++$ \\
Sri Lanka & -0.057 & 0.074 & 0.961 & 4.614 & 72.249 & $52.018+++$ \\
Thailand & -0.038 & 0.041 & 0.442 & 3.312 & 64.526 & $58.43+++$ \\
Indonesia & -0.036 & 0.021 & 0.312 & 4.322 & 67.166 & $78.53+++$ \\
\hline Australia & 0.064 & 0.004 & 0.703 & 3.587 & 33.914 & $41.79+++$ \\
Korea & 0.049 & 0.028 & 1.109 & 4.594 & 41.689 & $55.55+++$ \\
China & 0.091 & 0.033 & 1.905 & 5.965 & 41.242 & $30.02+++$ \\
India & 0.085 & 0.072 & 1.362 & 4.575 & 36.243 & $27.72+++$ \\
Japan & 0.096 & 0.004 & 0.903 & 5.587 & 24.414 & $21.59+++$ \\
\hline Regional & 0.098 & 0.032 & 1.290 & 4.178 & 47.916 & $44.22+++$ \\
\hline REER & 0.077 & 0.002 & 0.451 & 4.222 & 19.914 & $41.09^{+++}$ \\
\hline
\end{tabular}

Notes: This table shows the basic statistics and stochastic properties for stock returns in excess of the Eurodollar rates at one month and the exchange rate. Here, ${ }^{+},{ }^{++}$, and ${ }^{+++}$indicate that the null hypothesis of normality, of no autocorrelation, and of no $\mathrm{ARCH}$ effect is rejected at the $10 \%, 5 \%$, and $1 \%$ levels respectively.

\section{Empirical Results}

\subsection{Regional Market Prices and Foreign Exchange Risks}

Table 1 shows that the exchange risk price is driven mainly by the excess dividend yields of the world market and the return of the regional market index. We employ the Wald test to investigate the null hypotheses that the exchange risk price is zero and constant. The results, reported in Panel $\mathrm{C}$ of Table 1, indicate the rejection of these null hypotheses at the $1 \%$ level. 
These findings effectively agree with those of previous studies, including Carrieri et al. (2007) and Tai (2007), that the exchange rate risk is a relevant risk factor for asset pricing in emerging markets and that it changes over time. The GARCH coefficients reported in Panel D of Table 2 are significant. Coefficients $a$ are small, indicating that conditional volatility does not change very rapidly. However, coefficients $b$ are large, indicating gradual fluctuations over time. One of the advantages of our approach is its authorization of asymmetric variance and covariance effects; the significant coefficients in vector $\boldsymbol{g}$ indicate that the conditional variance is higher after shocks that are large in absolute value. The significant coefficients in $g$ have a negative sign, showing that the conditional covariances between the stock markets of Indonesia and of the ASEAN-5 increase after large common negative or positive shocks.

Table 2. Prices of regional market and real exchange rate risks

\begin{tabular}{|c|c|c|c|}
\hline Constant & RIDY & RRENT & RPRM \\
\hline \multicolumn{4}{|l|}{ Panel A: Price of exchange rate risk } \\
\hline \multirow{2}{*}{ Indonesia } & $0.015 * *$ & $-0.06 * * *$ & 0.017 \\
\hline & $(0.003)$ & $(0.004)$ & $(0.025)$ \\
\hline \multicolumn{4}{|l|}{ Panel B: Price of regional market risk } \\
\hline \multirow{2}{*}{ Asia } & $0.061 * *$ & $0.007 * * *$ & $0.004 * * *$ \\
\hline & $(0.072)$ & $(0.0005)$ & $(0.001)$ \\
\hline \multicolumn{4}{|c|}{ Panel C: Specification test of price of regional and exchange rate risk } \\
\hline \multicolumn{2}{|c|}{ Null Hypothesis } & $\chi^{2}$ & p-value \\
\hline \multicolumn{2}{|c|}{$\begin{array}{l}\text { The price of market risk of the South Asian region is equal to } \\
\text { zero? } H_{0}: \alpha_{\text {reg }}=0\end{array}$} & $111.230 * * *$ & 0.000 \\
\hline \multicolumn{2}{|c|}{$\begin{array}{l}\text { The price of market risk of the South East Asian region is } \\
\text { constant? } H_{0}: \alpha_{\text {reg }}=1\end{array}$} & $224.111 * * *$ & 0.000 \\
\hline \multicolumn{2}{|c|}{$\begin{array}{l}\text { The price of exchange rate risk of the South Asian market is } \\
\text { jointly zero? } H_{0}: \alpha_{k}=0\end{array}$} & $114.152 * * *$ & 0.000 \\
\hline \multicolumn{2}{|c|}{$\begin{array}{l}\text { The price of exchange rate risk of the South Asian market is } \\
\text { jointly constant? } H_{0}: \alpha_{k}=1\end{array}$} & $111.455^{* * *}$ & 0.000 \\
\hline
\end{tabular}

Panel D: Parameter estimates of GDC-GARCH process

\begin{tabular}{|c|c|c|}
\hline & Indonesia & Region \\
\hline$A$ & $\begin{array}{l}0.325 * * * \\
(0.034)\end{array}$ & $\begin{array}{l}0.285 * * * \\
(0.053)\end{array}$ \\
\hline B & $\begin{array}{l}0.475 * * * \\
(0.051)\end{array}$ & $\begin{array}{l}0.505 * * * \\
(0.014)\end{array}$ \\
\hline$G$ & $\begin{array}{l}0.031 \\
(0.063)\end{array}$ & $\begin{array}{l}-0.025 * * * \\
(0.009)\end{array}$ \\
\hline
\end{tabular}

Notes: RIDY (dividend yield of the region in excess of the 30-day Eurodollar interest rate), RRENT (return of regional market index), RPRM (regional term premium); $\boldsymbol{a}, \boldsymbol{b}$, and $\boldsymbol{g}$ are vectors of unknown parameters in Eq. (1) and ${ }^{* *}$ and ${ }^{* * *}$ indicate that the coefficients are significant at the $5 \%$ and $1 \%$ levels respectively.

However, fluctuations in the regional stock market constitute a source of systematic risk in 
the context of our asset-pricing model with partial integration. Contemporary international finance theory suggests that this risk is significant and priced: the greater the risk, the higher the risk reward. The price of the regional market risk (see Table 1, Panel B) appears also to be significantly and positively explained by all the regional variables: the dividend yield of the region in excess of the 30-day Eurodollar interest rate and the return of the regional market index and region term premium (RPRM). We investigate the economic significance of the risk factor by testing the null hypotheses that the price of risk is equal to zero or constant. The results of the Wald test (reported in Table 1, Panel C) indicate the rejection of these null hypotheses at the $1 \%$ level. These findings effectively concur with those of previous studies such as Adler and Dumas (1983), Carrieri et al. (2007), Hardouvelis et al. (2006), and Guesmi and Nguyen (2011).

\subsection{Intra-regional financial market integration analysis}

Table 3 reports the time-varying measure of market integration, obtained by estimating the whole system of equations (2) while imposing the estimates from the subsystem for regional and exchange rate index returns. The statistical significance of most coefficients associated with the U.S. term premium and the level of market openness. We have attempted to estimate our model with various numbers of market integration determinants, but the specification with two factors (trade openness and U.S. term premium; Guesmi and Nguyen, 2014) avoids the convergence problem and provides the best fit to the data, as witnessed by the AIC, BIC, and log-likelihood criteria.

Table 3. Dynamics of stock market integration

\begin{tabular}{llll}
\hline Panel A: Parameters of the market integration measure & & \\
& Constant & MOPN & UPRM \\
& 0.221 & $0.207 * * *$ & $0.032^{* * *}$ \\
& $(0.342)$ & $(0.011)$ & $(0.001)$ \\
\hline Panel B: Statistics of market integration & & & \\
& p mean & $p$ max & p min \\
& $0.463 * * *$ & 0.764 & 0.102 \\
& $(0.179)$ & & \\
\hline
\end{tabular}

Panel A: Parameters of the market integration measure

Constant MOPN UPRM

$0.221 \quad 0.207 * * * \quad 0.032 * * *$ 


$$
(0.342) \quad(0.011) \quad(0.001)
$$

\begin{tabular}{llr}
\hline Panel $C$ : Specification test of price of local risk & \\
Null Hypothesis & $\chi^{2}$ & p-value \\
\hline $\begin{array}{l}\text { Is the price of local risk in Indonesia zero? } \\
\text { Is the price of local risk in Indonesia }\end{array}$ & $70.39 * * *$ & 0.000 \\
constant? & 0.000
\end{tabular}

Notes: ${ }^{*},{ }^{* *}$, and ${ }^{* * *}$ indicate that the coefficients are significant at the $10 \%, 5 \%$, and $1 \%$ levels respectively; ${ }^{+},{ }^{++}$, and ${ }^{++}$indicate that the null hypothesis of normality and autocorrelation is rejected at the $10 \%, 5 \%$, and $1 \%$ levels respectively.

Figure 1 depicts the time-paths of the financial integration measure. Since the beginning of the 2000s, this region has exhibited increasing integration following greater stock market liberalization and economic cooperation both regionally and internationally. Indonesian financial integration began in the late 1980s with structural reforms aimed at stimulating the private sector and opening markets to foreign investors. A close inspection of the nation's integration patterns indicates a level of integration greater than 0.50 during a crisis period (2001-2002) and a sharp increase in integration beginning in 2003. The deepening financial integration of recent years can be explained by referencing Asia's greater openness to foreign trade, high growth rates, and the impacts of international financial shocks. According to Bormann et al. (1995), growth seems to be the main factor in Asia's strengthening regional and global integration. The economic success of Japan and of newly-industrialized countries has encouraged private firms to invest in the region's developing nations, thereby improving the dynamics of regional financial markets.

Though preferring regional to global financial integration has no theoretical justification, an Asia-wide consolidation of domestic capital markets could produce a number of benefits. In the long term, it may help create a market with a scale, depth, and liquidity sufficiently attractive to international and regional investors, thus reducing costs and improving the value of price signals. Economic cooperation between neighboring countries not only strengthens their economic and financial integration but also enhances political stability (Chowdhury, 2005). Thus, regional cooperation may be useful in setting common standards for domestic capital markets and cross-border issues of financial products. The creation of ASEAN, which aims to remove trade barriers among its member countries, is a first step in this direction.

Figure 1. Dynamic integration of Indonesia into the regional market 


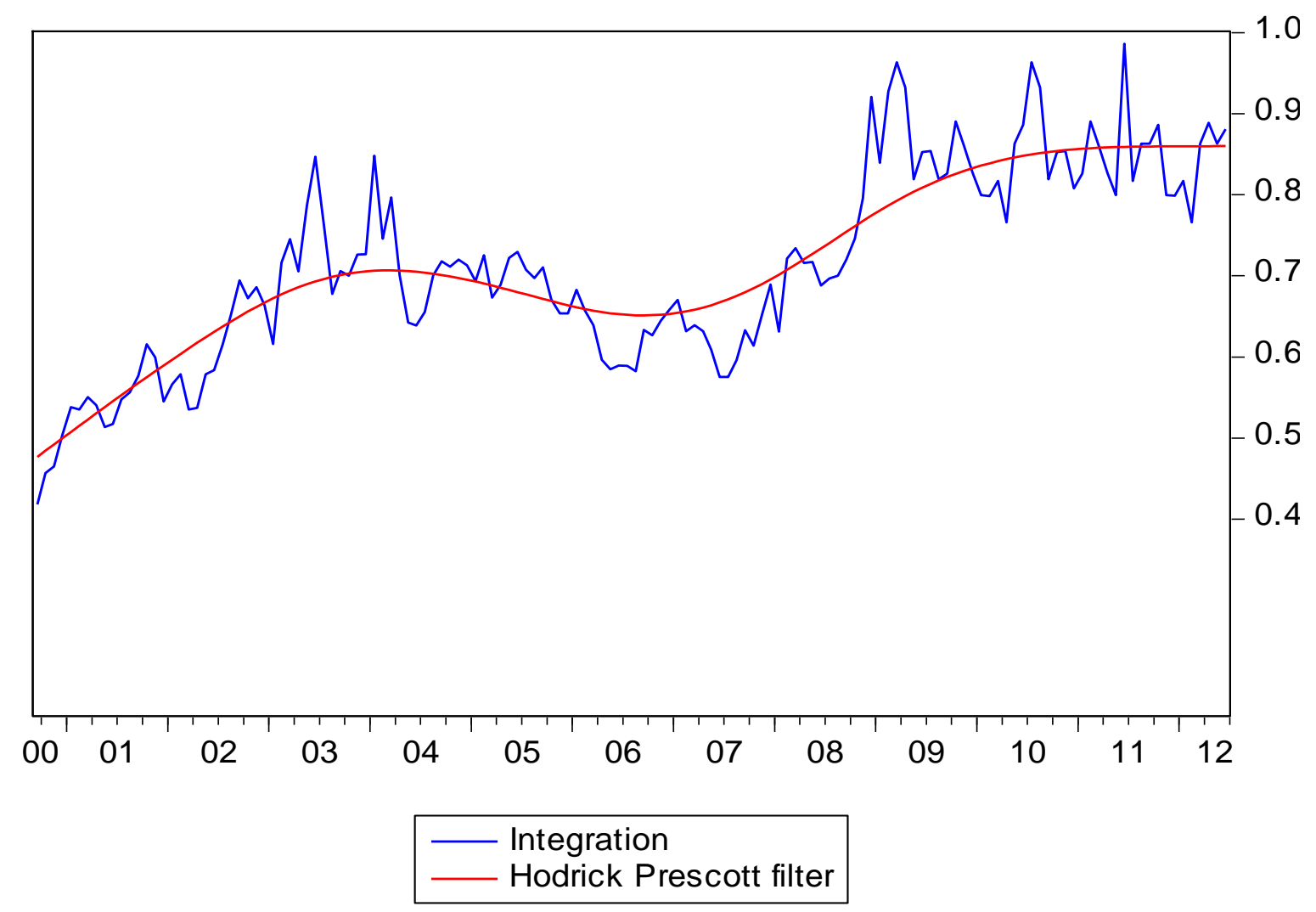

We examine here, first, the financial implications of greater market integration and, second, the barriers that may explain Indonesia's lower integration into regional finance since the early 2000s.

Indonesia is relatively financially isolated because it is less open to foreign trade than are most Asian countries. The country is less affected by global industrial downturns because the weight of its manufacturing sector is less prominent than in other Asian countries, and the structure of its GDP is more diverse. Its lower capital market liberalization and underdeveloped financial markets and institutions may also have contributed to Indonesia's relatively low regional integration (Eichengreen and Park, 2005). Moreover, Indonesia lacks an anchor country or financial center that could mediate financial transactions ( $\underline{\text { Kim } e t ~ a l .,}$ 2008).

The lack of regional financial integration between Indonesia and Asia can also be explained by citing $i$ ) the region's small and underdeveloped domestic capital markets; ii) the heterogeneous nature of the region and the size inequalities between countries; iii) the licensing and other regulatory practices that discriminate ex post against the cross-border activity of Asian banks; and iv) the capital account restrictions that limit the scope for twoway capital flows. 
The observed changes in regional integration levels are crucial: beyond financial integration's benefits (i.e., greater risk diversification, better capital allocation, higher economic growth potential), it may also induce adverse effects such as financial instability, abrupt capital flow reversals, and shock contagion. Studies such as Levine and Zervos (1996), Stiglitz (2002), Bekaert et al. (2002), and Bekaert et al. (2005) have found increasing financial instability following increased financial liberalization and market integration to be important threats to emerging markets. When the Indonesian stock market is more open to international capital flows, it is also more vulnerable to external contagious shocks. The risk of high volatility has been manifested by successive crises in the ASEAN market over the last two decades (e.g., the Mexican peso crisis of 1994-1995, the Asian crisis of 1997-1998, the Russian crisis of 1998, the collapse of the Brazilian real in 1999, the Argentine peso crisis of 2001-2002). Our finding on the high degree of intra-regional integration should help policymakers at both national and regional levels implement appropriate economic policy adjustments when the next financial crisis hits the ASEAN region. Moreover, as the region's stock market integration levels change over time with respect to both regional and local risk factors, our partially integrated ICAPM can help in determining the market risk premia and the corresponding capital costs. Indeed, investments in Indonesia with low levels of market integration command high-risk premia and high capital costs.

\subsection{Total risk Premium Analysis}

Regional risk plays a statistically significant role in determining the equilibrium value of asset returns. In this sub-section, we assess the economic importance of the risk premium. The total risk premium (TRP) can be divided into two components: regional risk premium (RRP), containing the regional market risk and exchange rate risk premium, and the local risk premium (LRP):

$$
\begin{aligned}
& T R P={ }_{t 1} \quad \text { reg,t } t 1 h_{\text {Indonesia, } t}+{ }_{k, t} h_{\text {Indonesi } k, t,}+\left(\begin{array}{ll}
1 & { }_{t 1}
\end{array}\right)_{t 1} h_{\text {Indonesia }, t} \\
& R R P={ }_{t 1} \quad{ }_{\text {reg, }, t} h_{\text {Indonesia }, t}+{ }_{k, t} h_{l} h_{\text {Indonesi }, k, t,} \\
& L R P=\left(\begin{array}{ll}
1 & { }_{t 1}
\end{array}\right)_{t 1} h_{\text {Indonesia }, t} \\
& T R P=R R P+L R P
\end{aligned}
$$

Summary statistics for the estimated premiums are reported in Table 5. Due to the small 
values of the regional market risk premium, the local premiums are considerably lower than are the corresponding premiums for the regional markets. The sample's smallest total premium value is $8.789 \%$. The importance of the regional premium varies from one subperiod to another depending on its degree of segmentation and the quantity of its regionally undiversifiable risk.

The annualized estimated regional premia range from 5.349\% (1996: 03 - 2012: 12) to 7.789\% (2008: 05 - 2012:12). ${ }^{2}$ When we compare the sub-periods (1996:03 - 2008:05) and (2008:05 - 2012:12), we see that the role of regional risk factors in determining the total premium remains important and has significantly increased. At the end of our sample, the regional premium started to play a more significant role in the total risk premium, and its weight as percentages of the absolute total premium increased. These results suggest that regional factors are playing an increasing role in pricing emerging market regions.

However, we have shown that segmentation has increased from $3.320 \%$ to $4.120 \%$. This result is expected, given the high-risk exposure of the ASEAN region (e.g., repeated political and economic crises after 2008). The risk premium associated with the local risk is regionally undiversifiable and is a statistically and economically significant component of the total risk premium. The relative importance of this risk premium has increased in recent years from $3.320 \%$ to $4.120 \%$. The strong integration of the Singaporean stock market is caused by the small contribution of the local risk premia in the total premium, which is dominated by regional factors and events.

Table 5: Decomposition of the total risk premium

\begin{tabular}{ccc}
\hline $1996-2008$ & $2008-2012$ & $1996-2012$ \\
\hline TRP & TRP & TRP \\
$9.509^{+++}$ & $11.909^{+++}$ & $8.789^{+++}$ \\
$(0.170)$ & $(0.170)$ & $(0.122)$ \\
\hline RRP & RRP & RRP \\
$6.189^{+++}$ & $7.789^{+++}$ & $5.349^{+++}$ \\
$(0.122)$ & $(0.122)$ & $(0.122)$ \\
\hline LRP & LRP & LRP \\
$3.320^{+++}$ & $4.120^{+++}$ & $3.440^{+++}$ \\
$(0.130)$ & $(0.130)$ & $(0.130)$ \\
\hline
\end{tabular}

Notes: ${ }^{+++}$indicates that the average risk premia are significantly different from zero at the $1 \%$ level with respect to the two-sided Student's-t test.

\footnotetext{
2 The financial crisis was found on the 2008:M5 using the test in Bai and Perron (2002). The Bai-Perron test is based upon an information criterion in the context of a sequential procedure, and enables finding the number of breaks implied by the data, as well as estimating the timing of the breaks and the parameters of the processes between them.
} 
Table 6 shows the model's residuals analysis, conducted to study their normality, autocorrelation, and conditional heteroscedasticity. The normality of the estimated residuals can be accepted. The 1982 Engle's test for conditional heteroscedasticity of the standardized residuals indicates that $\mathrm{ARCH}$ effects no longer exist in all cases, thus revealing the appropriateness of the GARCH modelling approach.

Table 6: Residuals analysis

\begin{tabular}{lccccc}
\hline & Skewness & Kurtosis & J.B & $\mathrm{Q}(6)$ & ARCH (1) \\
Indonesia & 0.333 & 7.666 & 22.356 & 7.765 & 0.333 \\
Region & $1.514^{* * *}$ & $16.244^{* * *}$ & $10.131^{+++}$ & 13.456 & 0.115 \\
\hline
\end{tabular}

\begin{abstract}
Notes: Numbers in parentheses are the associated standard deviations. JB, Q(6), and ARCH(1) are, respectively, the empirical statistics of the Jarque-Bera test for normality, the Ljung-Box test for serial correlation of order 1, and Engle's (1982) test for conditional heteroscedasticity. Moreover, ${ }^{*}, * *$, and ${ }^{* * *}$ indicate that the coefficients are significant at the $10 \%, 5 \%$, and $1 \%$ levels, respectively. Finally, ${ }^{+},{ }^{++}$, and ${ }^{+++}$indicate that the null hypothesis of normality and autocorrelation is rejected at the $10 \%, 5 \%$, and $1 \%$ levels respectively.
\end{abstract}

\title{
7. Conclusion
}

This paper studies the dynamics of the Indonesian stock market's regional integration, taking into account the importance of the exchange rate and local market risk. An international capital asset pricing model suitable for partially integrated markets and a departure from purchasing power parity was developed in the spirit of the regime-switching model in Bekaert and Harvey (1995) to explain the time-variations in expected returns on regional emerging market indices. In its fully functional form, the model allows the market integration measure and the regional and local risk premiums to vary over time.

We find that the level of market integration varies widely over time and is satisfactorily explained by the degree of trade openness and variation in the US term premium. Though it reaches fairly high values during several periods and exhibits an upward trend towards the end of the estimation period, the Indonesian stock market remains partially integrated into the ASEAN-5 region.

The average premium for local risk appears to be only a small fraction of the average of the total premium during the entire sample, suggesting that diversification into emerging market assets continues to produce substantial profits and that asset pricing rules should reflect a state of partial integration.

\section{References}

Adler, M. and Dumas, B. (1983), "International portfolio selection and corporation finance: A synthesis", Journal of Finance 38, 925-984. 
Adler, M. and Qi, R. (2003), “Mexico's Integration into the North American Capital Market”, Emerging Economic Review 4, 91-120.

Bekaert, G. and Harvey, C.R. (1995), “Time varying world market integration”, Journal of Finance 50 (2), $403-$ 444.

Bekaert, G., Erb, C.B., Harvey, C. and Viskanta, T. (1998), Distributional characteristics of emerging market returns and asset allocation, Journal of Portfolio Management 24, 102-116.

Berger, T. and Pozzi, L. (2013), "Measuring time-varying financial market integration: An unobserved components approach", Journal of Banking \& Finance 37, 463-473.

Black, F. (1974), "International capital market equilibrium with Investment barriers", Journal of Financial Economics 1, 337-352.

Borensztein, E. and Loungani, P. (2011), “Asian financial integration: Trends and interruptions”, IMF Working Papers No 11/4.

Borrmann, A., Bernhard, R., Georg K. and Hans-Eckart, S. (1995), Regionalisierungstendenzen in Amerika, Nomos Verlagsgesellschaft, Baden Baden.

Carrieri, F., Errunza, V. and Hogan, K., (2007), "Characterizing world market integration through time", Journal of Financial and Quantitative Analysis 42 (4), 915-940.

Chambet, A. and Gibson, R. (2008), "Financial integration, economic instability and trade structure in emerging markets", Journal of International Money and Finance 27, 654-675.

Chowdhury, M.B. (2005), "Trade reforms and economic integration in South Asia; SAARC to SAPTA", Applied Econometrics and International Development 5 (4), 23-40.

Claessens, S. and Rhee, M. (1994), "The Effect of Barriers to Equity Investment in Developing Countries", in: The Internationalization of Equity Markets, Frankel, J., (ed.), University of Chicago Press, Chicago and London, 231-275.

Eichengreen B. and Park, Y.-C. (2005), Financial liberalization and capital market integration in East Asia, The EU Center of the University of California, Berkeley and the Ford Foundation.

Engle, R. (1982), "Autoregressive conditional heteroscedasticity with estimates of the variance of U.K Inflation”, Econometrica 50, 987-1008.

Errunza, V. and Losq, E. (1985), "International asset pricing under mild segmentation: Theory and test”, Journal of Finance 40, 105-124.

Forbes K. and Chinn, M. (2003), “A Decomposition of Global Linkages in Financial Markets Over Time”, NBER Working Paper No. 9555.

Grubel, H. (1968), "International diversified portfolio: welfare gains and capital flows", American Economic Review 58, 1299-1314.

Guesmi, K. and Nguyen, D.K (2011) "How strong is the global integration of emerging market regions? An empirical assessment”, Economic Modelling, Vol. 28, pp. 2517-2527.

Guesmi, K. and Nguyen, D.K. (2014), “Time-varying regional integration of stock markets in Southeast Europe", Applied Economics, 46 (11), pp. 1279-1290.

Guesmi, K. and Teulon, F. (2014), "The determinants of regional stock market integration in middle east: A conditional ICAPM approach”, Economie Internationale, 137, pp. 22-31.

Guesmi K., Moisseron J.-Y., Teulon F., 2014. "Integration versus segmentation in Middle East North Africa equity market: Time variations and currency risk", Working Papers 2014-293, Department of Research, Ipag Business School.

Hardouvelis, G. A., Malliaropulos, D. and Priestley, R. (2006), “EMU an European stock market integration”, Journal of Business 79 (1), 365-373.

Harvey, C.R. (1995), “The risk exposure of emerging equity markets”, World Bank Economic Review 9, 19-50.

Kim, S., Lee J.-W. and Shin, K. (2008), "Regional and global financial integration in East Asia", in: Eichengreen B., Park Y.C. \& Wyplosz C. (eds), China, Asia, and the New World Economy, Oxford: Oxford University Press, 168-200. 
Kroner, F. and Ng, V.K. (1998), "Modeling Asymmetric Comovements of Asset Returns", The Review of Financial Studies 11 (4), 817-844.

Levy, H. and Sarnat, M. (1970), "International Diversification of Investment Portfolios", American Economic Review 60 (4), 668-675.

Markowitz, H. (1952), “Portfolio Selection”, Journal of Finance 7, 77-91.

Nguyen D.K. and Deora, R. (2013), "Time-scale comovement between the Indian and world stock markets", Journal of Applied Business Research 29 (3), 765-775.

Stehle, R. (1977), An empirical test of the alternative hypotheses of national and international pricing of risky assets, Journal of Finance 32, 493-502.

Tai, C-S., 2007. Market integration and contagion: Evidence from Asian emerging stock and foreign exchange markets. Emerging Markets Review. 8, 264-283.

Tse, Y.K. and Tsui, K.C. (2002), “A multivariate GARCH model with time-varying correlations”, Journal of Business \& Economic Statistics 20 (3), 351-362. 